\title{
Ethical Standards in the International Civil Service
}

\author{
Phd. Julejda Gërxhi \\ Department of Law, "Pavaresia"University" Vlore, Albania \\ Email: julejda@gmail.com
}

\section{Doi:10.5901/mjss.2014.v5n20p892}

\begin{abstract}
International civil service relies on some traditional principles of public administration which are: competence, integrity, impartiality, independence and discretion. Based on these principles of international civil servants should be placed in the motto to serve the observance of fundamental rights, economic and social progress and international cooperation. Ethical values embodied by the Organization of the United Nations, should also be a guide for international civil servants to focus all of their activities, to maintain respect for social justice, dignity and human values, respect for the equal rights of large and small nations. This project aims to: Firstly, handling ethical standards in the international civil service, highlighting a positive and active approach to their respect by national laws, who should feel responsible for contributing to the ideals in which they should be involved in implementing the dedication. Secondly, the awareness of civil servants that respect ethical standards ensures the fact that international civil service will continue to be an effective instrument in fulfilling its responsibilities and fulfill the aspirations of the public worldwide
\end{abstract}

Keywords: ethical standards, international civil service, civil servants, integrity, discretion..

\section{Introduction}

Administrative tradition varies depending on the culture of a country, but there are common views and how civil servants should accomplish their duties in a fair, honest and efficient.

However these values may conflict with what is expected. For example, family members and others may believe that they must be provided job guarantees continuity despite political changes affecting political officials.

On the back of a family member who is employed in the public sector, exercised great pressure, because it is expected to care for other family members even when the wage level satisfies difficulties to meet the personal needs pressing public officials.

On top of these pressures show some situations where it becomes difficult to obtain the right decision, so civil servants should implement standards that he knows and understands, and on their basis, can make ethical decisions. He may be given confidential advice, if feels it needs to. (http:/strategis.ic.gc.ca/epic/internet/inoec-bce.nsf/ www.Generatedinter E/home)

Most of people would like that the civil servant was honest and respected for his personal integrity. This assertion is accurate and provides a starting point for ethics management system that has the potential to make trouble for unethical behavior.

This unethical behavior is the result of misunderstandings and misperceptions, as well as open lawlessness. (http:/www.worldbank.org/publicsector/civilservice/siternap.htm)

In such an environment it is easy to understand what is right and what is unjust.

Today in developed countries but also in developing countries, civil service pressures come for various reasons, such as:

- delegation of responsibilities, including financial responsibilities within the public administration bodies;

- influence that media exerts on civil servants, forcing them to display their negative side as a result of provocations that have been made;

- increasing willingness of the public to complain when public service quality is low.

All these have contributed to increasing awareness about the need to take steps to support the ethical basis on which the civil service will function.

Many transition countries have had to confront with "inherited skeleton of a demoralized civil service and a badly operating, often nonpayment by accomplishing whatever they can survive with oppression of the people of deficient services offered". 
Public management reforms, which include a greater delegation of responsibilities and greater discretion for public employees, budgetary pressures and new forms of public service delivery, have challenged traditional values of public service.

It may not have changed ethics, but in the modern civil service management space is expanded freedom of action in many areas (Reform).

Surveillance has shown that many countries may exacerbate rather hostility towards people state structures. This is also reflected in the international level. Thus, the member states of the Organization for Economic Cooperation and Development (OECD) have participated in the comparative observations to strengthen its ethics programs.

In 1996 the OKB declared an international code of conduct for public officials. Specifically: Resolution 51/59, "Actions taken against corruption", adopted by the General Assembly on 12 December 1996, which served as a guiding tool for the fight against corruption (E/6/ADD.1). The code is similar to the model code of conduct of public officials of the Council of Europe, 2000. Code contains some binding issues, but the document itself is seen as a recommendation and is intended to be taken as a precedent for those countries that are developed their own codes of conduct binding. Some of the standards set in, addressing a similar theme with the text of the Organization of the United Nations.

However the text of the Council of Europe leads to behavioral aspects of public administration and policy relating to anticorruption policies. Article 6, which deals with arbitrary actions are, elaborated enough to cover problems, such as: general discrimination and conduct that can be imbalanced by the impact of corruption.

Standards of conduct for the international civil service are approved by the International Civil Service Commission in consultation with the Organization of the United Nations.

\section{Essential Conditions for an Ethical Public Administration}

Essential conditions for an ethical public administration are:

- Clear rules and guidelines which are based on mutual understanding, shared values and principles. These values must be politically neutral and applicable, even if the government changes;

- direction from senior officials that inspire respect;

- raise professional values;

- state wide participation in a discussion about the code of ethics;

- appropriate mechanisms of accountability;

- scale dissemination of codes of ethics and other documents related to the ethics and standards that are expected to be achieved;

- training of civil servants on the implementation of a code of ethics for ethical decision making;

- stimulate employees to implement the rules of ethics;

- nonpartisan functioning of structures based on the performance of the code of ethics, this shall contain such standard that every employee, regardless of political beliefs, supports them.

Starting from these principles of international civil servants, should be placed in the motto to serve respecting fundamental rights, economic and social progress and international cooperation. On the other hand public administration schools should play an important role for the development of standards (Hooligan, (2009)) of their country, and their involvement in ethical structures that treat public officials.

Values that are embodied by the Organization of the United Nations should also be a guide for international civil servants to focus all of their activities, to maintain respect for social justice, dignity and human values, respect for the equal rights of nations large and small (UN.E/6/ADD.).

International civil service is based on the great traditions of public administration are: competence, integrity, impartiality, independence and discretion. (http/www.legislation.qld.gov.au./LEGISLTN/CURRENT/Ë/WhisstleblowA94. pdf)

The concept of integrity enshrined in the Charter of the United Nations includes all aspects of the behavior of an international civil servant, including such qualities as honesty, truthfulness, impartiality and incorruption.

These qualities are essential as well as competence and efficiency, also enshrined in the International Bill.

Tolerance and understanding are fundamental values, but also essential for international civil servants, who must respect all individuals equally, without discrimination of any kind.

This fosters a climate of respect and a work environment sensitive to everyone's needs.

Fairness in service content, particularly in the political treatment is one of the international civil service values. This quality does not violate personal political views or national perspectives, civil servants, which remain intact. 
However they do not have the freedom of individuals to express their views publicly in work environments, controversial issues, either individually or as members of a group.

This means that, in certain situations, personal views should only be expressed with tact and caution, outside the context of the civil service. Freedom from discrimination is a fundamental right of the civil service.

International civil servants should tend towards respecting equality without difference.

Assumptions based on stereotypes should be avoided with perseverance.

One of the main principles of the Organization of the United Nations Charter's equality of men and women, in order to promote gender equality.

Freedom from discrimination also means respect for different cultural patterns. This requires a willingness to work without bias with people of all nationalities, religions and cultures, which mean punctilious avoidance of any expression that can be interpreted as unilateral or intolerant. Working methods may be different in culture different, but they cannot be biased, as long as respect the general rules and specific.

Fidelity to the civil service ensures the integrity and positive outlook that civil servants will decide the general interests to personal interests, despite the temptations of the moment. It also means using resources in the civil service responsibly.

Managers and supervisors of the civil service are in positions of leadership, and is their responsibility to ensure a harmonious workplace based on mutual respect, which means that the possibility of involvement in the civil service are open to all professionals. They need to provide support to civil servants, especially when they are subjected to criticism arising from the performance of their duties. (http:/www.transparency.org/sourcebook/20.htm/)

Managers are also responsible for guiding and motivating their staff and promote the development of professionalism.

Respect to the best models of meritocracy promotes respect for the highest standards of conduct. If this principle does not appear misconduct, gifts or loans from their staff, which will be under the pressure of losing one's job, which will affect the quality of the civil service.

Decision-making procedures by managers or supervisors of the civil service should be transparent, so they decide bridges as effective communication with their staffs.

Only in these conditions civil servants feel a mutual responsibility to provide all the facts and information to their supervisors in defense decisions, even when these do not coincide with their own professional beliefs.

Civil servants must remain independent of any authority outside their organizations, and their own behavior should reflect that independence. In accordance with the loyalty of their duty, they should not accept instructions from any entity outside of their employing organization.

Civil servants have to follow the instructions they receive in connection with their official functions, and if they have doubts whether an instruction is contrary to law or rule, you should first consult with their supervisors.

If you do not find consensus, may require written instructions, which can be countered by appropriate institutional mechanisms. This way works for guidelines that are clearly inconsistent with their official functions or that threaten their safety or others. They must report any violations of the rules by a high level official, whose responsibility is to take appropriate measures.

A civil servant, who makes such a report in good of the institution and the public, has a right to be protected against reprisals or sanctions by the senior subjective breaker rules.

Conflict of interest is a challenge to the standards of behavior of civil servants.

Conflict of interest includes circumstances in which a civil servant, directly or indirectly, to benefit itself creates illegally, or allow a third party to benefit illegally.

Civil servants should avoid the help of private bodies or private persons in their relations when it can lead to perceived preferential treatment. This is especially important in the field of public procurement, or in negotiations for future employment.

To prevent such conflicts, civil servants should voluntarily make known in advance potential conflicts of interest that arise during the performance of their duties. They must perform their official duties and their private affairs in a manner to uphold the public trust in the integrity of their personal and institutional. (http:/www.ipe.org)

To protect international civil service from any appearance of impropriety, civil servants must not accept, without authorization, any favor, gift, reward, favor or economic benefit of more than nominal value allowed from any external source. Also civil servants should not receive additional payments or other subsidies from other sources before, during or after exercise of civil service duties, if the payment is related to that task /duty.

Freedom of association is a fundamental human right and civil servants have the right to form trade unions or other professional groups that promote and protect their interests. 
Direct relationship between supervisor and staff should be guided by mutual respect.

Elected representatives of civil servants, have a cardinal role in the protection of the right to good working conditions, as well as all staff welfare issues.

Elected representatives of civil servants enjoy the rights deriving from their status, and this may include the opportunity to address the legislative bodies of their organization. These rights must be exercised in a manner that is in accordance with national legislation and international conventions on human rights.

Representatives of civil servants should be protected against discriminatory actions that affect their status or activities as a representative of civil servants during their authorization as well as after it is completed. (http:/www. usoge.gov)

There is a risk that if a civil servant may be subject to criticism of individuals, in accordance with their responsibility, they should respond with tact and caution.

However they have a right to be protected from the institution where they work against criticism for actions taken in the performance of their duties.

Civil servants should strive/try at all before to promote a positive image of the civil service, in accordance with the principle of loyalty.

Transparency in dealings with the media is the most effective tool in communicating messages about the work in the civil service.

Civil servants should consider themselves as legal representative on behalf and for the account of the institution they represent and to avoid references and personal views.

In any case they cannot use the media to further their interests, their complaints, unauthorized disclosure, or try to influence policy decisions facing the institution.

Confidentiality is one of the important principles in the civil-service. Disclosure of confidential information could jeopardize/risks seriously the efficiency and credibility of an institution (White Paper 1443/2004 Forholdet mellem minister og embedsmænd, 2004).

Civil servants are responsible for the exercise of discretion in all official matters. They should not disclose confidential information without authorization, and should not use information that is not made public and why are familiar with because of their official position.

Prohibition of unfair competition is an obligation of every employee who ceases after separation from service. This principle is necessary for institutions to maintain guidelines for the use and protection of confidential information, and it is equally necessary to keep pace with developments in communication technology.

Service needs are the responsibility of institutions to ensure the health, welfare and lives of their staff, without any discrimination, so that the civil servant shall not be subject to unnecessary risk. Institutions involved in the civil service should take measures to protect the security of civil servants and their family members.

Private life of civil servants is guaranteed by law, and employing institutions should not interfere. (http://www.legislation.qld.gov.au/LEGISLTN/ACTS/1994/94AC067.pdf)

However, if found situations in which the conduct of a civil servant can reflect on the image of the institution , he is responsible for this behavior and is exposed to taking disciplinary measures .

The main duty of civil servants is to commit to all professional energies within their institution, and any engagement in outside activities, with or without compensation, without prior authorization of the institution responsible constitutes a disciplinary offense.

In the event that the institution deems reasonable outside engagement in professional activities that serve to maintain and improve the technical competence of civil servants, allows and encourages them to grow professionally.

\section{Conclusion}

Achieving the standards of conduct for the international civil service requires the highest commitment of all parties involved in the civil service.

Civil servants to be called part of the system must be committed to the values, principles and standards set internationally.

They should have a positive and active approach to their respect, and should feel responsible for contributing to the ideals in which they should be included with dedication.

- That these standards are implemented effectively, it is essential that they be widely known and taken measures to ensure that the scope and significance are understood to apply.

- Ethical orientation must be disclosed to civil servants. Professional association should help to develop the 
skills and judgment necessary to enable civil servants to apply ethical principles in concrete circumstances. Training facilitates ethics awareness, and can develop essential skills for ethical analysis and moral reasoning. Progress objective can help to create an environment where a civil servant is ready to face and resolve ethical problems to function successfully.

- Civil service, there must be public support. All civil servants have an ongoing responsibility to promote a better understanding of the objectives and work with dedication. This requires that they be well informed not only the achievements of the institution where they work, but also the civil service as a whole, to give information to the public at any time.

- Unethical behavior of civil servants should be punished with sanctions set.

Mechanisms procedures and sanctions for discovery and independent investigation of a breach are important parts of the infrastructure of ethics.

It is necessary to exist reliable procedures and resources for monitoring, reporting and investigating violations of the rules of public administration, administrative and disciplinary sanctions, proportionate to hit unethical behavior.

Superiors should exercise appropriate judgment in the use of these mechanisms,when action is taken. Mechanisms should be fair and reliable. They must protect the innocent and reveal the guilty.

- Penalties should be proportionate and consistently applied. If these punishments are not enforced, violations of ethics are not viewed more seriously by a civil servant, which means that ethical standards will go towards destruction.

Respect to these standards ensures that international civil service will continue to be an effective instrument in fulfilling its responsibilities and fulfill the aspirations of the public worldwide.

\section{References}

E/6/ADD.1, T. r.

Hooligan, J. ((2009)). 'Models of public administration and new roles of the state: exploring contradictions and patterns of change', paper for the panel Theoretical Perspectives on Government Organizations, European Consortium for Political Research, Gener. http//www.legislation.qld.gov.au./LEGISLTN/CURRENT/Ë/WhisstleblowA94.pdf. (n.d.).

http://www.legislation.qld.gov.au/LEGISLTN/ACTS/1994/94AC067.pdf. (n.d.).

http://www.legislation.qld.gov.au/LEGISLTN/ACTS/1994/94AC067.pdf. (n.d.).

http:/strategis.ic.gc.ca/epic/internet/inoec-bce.nsf/www.GeneratedinterE/home. (n.d.).

http:/www.ipe.org.

http:/www.transparency.org/sourcebook/20.htm/.

http:/www.usoge.gov.

http:/www.worldbank.org/publicsector/civilservice/siternap.htm. (n.d.).

Reform, C. f.

Reform, C. f.

UN.E/G/ADD., T. r.

White Paper 1443/2004 Forholdet mellem minister og embedsmænd, B. f. (2004). Forholdet mellem minister og embedsmænd, Betænkning fra udvalget om forholdet mellem minister og embedsmænd, Schultz, Copenhagen. 